A

$\mathrm{N}$

\title{
Sympozjum naukowe pt. Wolność sumienia i religii osób pozbawionych wolności. Aspekty prawne i praktyczne, Popowo 2-4 marca 2015 r.
}

Zagadnienia dotyczące wolności religijnej osób pozbawianych wolności, były przedmiotem ogólnopolskiego sympozjum naukowego, które odbyło się w dniach 2-4 marca 2015 r. w Ośrodku Szkolenia Służby Więziennej w Popowie koło Serocka. Organizatorami było Polskie Towarzystwo Prawa Wyznaniowego i Centralny Zarząd Służby Więziennej. Problematyka opieki duszpasterskiej w zakładach karnych zgromadziła bardzo dużą liczbę zainteresowanych gości. Byli wśród nich m.in. kapelani więzienni różnych wyznań, funkcjonariusze służby więziennej bezpośrednio zajmujący się problematyką ochrony wolności religijnej więźniów oraz przedstawiciele Ministerstwa Administracji i Cyfryzacji. Środowisko naukowe było reprezentowane przez przedstawicieli wielu ośrodków akademickich z kraju.

W imieniu organizatorów, uroczystego otwarcia dokonali prof. dr hab. Tadeusz J. Zieliński - prezes Polskiego Towarzystwa Prawa Wyznaniowego i płk Jarosław Kardaś - zastępca Dyrektora Generalnego Służby Więziennej. Obrady zostały podzielone na sześć bloków tematycznych, które toczyły się we wspólnych i równoległych sesjach.

Spotkanie otworzył wspólny panel zatytułowany: Konstytucyjne podstawy wolności sumienia i religii osób pozbawionych wolności. Jego moderatorem był prof. dr hab. Tadeusz J. Zieliński. W zamierzeniach organizatorów poruszane zagadnienia miały wprowadzić słuchaczy w tematykę uwarunkowań ustrojowych duszpasterstwa więziennego. W sesji znalazło się pięć wystąpień, które rozpoczął dr hab. Paweł Sobczyk, prof. UO, wygłaszając referat pt. Konstytucyjne prawo osób do korzystania z pomocy religijnej, tam gdzie się znajdują. Następnie zabierali głos kolejni prelegenci prezen- 
tujący następujące referaty: dr Piotr Wiśniewski (KUL) - Osoba pozbawiona wolności jako podmiot konstytucyjnej gwarancji wolności sumienia i religii; dr Anna Komadowska (KUL) - Prawo do korzystania z wolności religijnej a zasada humanitaryzmu, dr Marta Ordon (KUL), która zastępowała nieobecną dr Anetę M. Abramowicz (KUL) - Duszpasterstwo $w$ instytucjach penitencjarnych a zasada równouprawnienia zwiąków wyznaniowych. Aspekty prawne i dr Konrad Walczuk (UPH w Siedlcach) - Ograniczenia wolności sumienia i religii osób pozbawionych wolności a bezpieczeństwo państwa i porządek publiczny - aspekt konstytucyjny.

Wspólną cechą wymienionych przedłożeń, było uświadomienie słuchaczom, że więźniowie z racji posiadanej godności osoby ludzkiej są równoprawnymi podmiotami w zakresie korzystania $\mathrm{z}$ wolności religijnej. Zarówno ustawa zasadnicza, jak i akty prawne niższego rzędu, zawierają odpowiednie gwarancje i tylko od stosujących prawo zależy jak będą realizowane w praktyce.

Pierwszy panel zakończyła bardzo ciekawa dyskusja, która konfrontowała poglądy teoretyków prawa z poglądami osób, na co dzień stykających się z więzienną rzeczywistością i realnymi problemami. Po obradach odbyło się Walne Zgromadzenie Członków Polskiego Towarzystwa Prawa Wyznaniowego.

Następnego dnia zorganizowano trzy sesje. Dwie pierwsze toczyły się równolegle, a trzecia wspólnie dla wszystkich uczestników.

Moderatorem pierwszego panelu, zatytułowanego: Realizacja praktyk religijnych więźniów był ks. prof. nadzw. dr hab. Dariusz Walencik (UO). Referaty, które zostały zaprezentowane można podzielić na dwie kategorie. Pierwsza, obszerniejsza, gdzie znalazły się cztery przedłożenia, dotyczyła problemów o charakterze ogólnym, natomiast trzy ostatnie skupiały się na casusach funkcjonujących zakładów karnych. Jako kolejni zabierali głos następujący prelegenci: dr Anna Tunia (KUL) z referatem pt. Zawarcie matżeństwa cywilnego $w$ formie wyznaniowej przez osobę pozbawiona wolności. Autorka zajęła się kwestiami, jakie wyniknęły dla procedury zawierania związku małżeńskiego na skutek nowelizacji ustawy Prawo o aktach stanu cywilnego. Zbliżoną tematyką zajął się również dr Michał Skwarzyński (KUL), przedstawiając referat dotyczący Prawa człowieka do zawarcia związku matżeńskiego w formie wyznaniowej przez osobe pozbawiona wolności. W odróżnieniu od poprzedniego wystąpienia, jego uwaga została skoncentrowana na zagadnieniach teoretycznych i potraktowana w szerszym ujęciu przy uwzględnieniu standar- 
dów prawa międzynarodowego. Dr Michał Chajda (WSFiP w Bielsku-Białej) zaprezentował przedłożenie pt. Pełnomocnictwo do zawarcia matżeństwa $w$ formie wyznaniowej przez osobe pozbawiona wolności, rozważając zarówno teoretyczne, jak i praktyczne problemy zawarcia związku małżeńskiego przez reprezentanta prawnego. Na praktycznych zagadnieniach tajemnicy spowiedzi skupił się dr Marcin Wielec (UKSW), prezentując referat zatytułowany: Spowiedź osób tymczasowo aresztowanych jako wyraz realizacji zasady wolności sumienia $i$ religii versus unormowania k.p.k. $i$ k.k.w. Kolejne referaty prezentowały sytuację osadzonych $\mathrm{w}$ istniejących zakładach karnych. Zostały wygłoszone w następującej kolejności: dr Marek Bielecki (KUL) - Praktyki religijne osadzonych w Zakładzie Karnym w Zamościu, por. mgr Konrad Wierzbicki (ZK w Chełmie) - Praktyki religijne osób pozbawionych wolności w Zakładzie Karnym w Chetmie, dr Justyna Krzywkowska (UWM) i ks. mgr Marek Paszkowski (ZK w Barczewie) - Prawo osadzonych do opieki duszpasterskiej i wykonywania praktyk religijnych na przykładzie Zakładu Karnego w Barczewie. W przeprowadzonej dyskusji słuchacze zwrócili uwagę na to, że można zaobserwować dużą aktywność kościołów i związków wyznaniowych zaangażowanych w tworzenie opieki duszpasterskiej dla osób pozbawionych wolności.

Równolegle toczyła się sesja zatytułowana: Prawne podstawy wolności religijnej, której przewodniczył Dziekan Wydziału Prawa, Prawa Kanonicznego i Administracji KUL dr hab. Piotr Stanisz, prof. KUL. Organizatorzy zaplanowali, że zostanie wygłoszonych pięć referatów, jednakże $\mathrm{z}$ uwagi na absencję prelegentów zaprezentowane zostały jedynie trzy wystąpienia. Jako pierwszy głos zabrał dr hab. Mieczysław Różański, prof. UWM. Jego referat zatytułowany został: Kapelan więzienny. Prawne podstawy duszpasterzowania. Autor opierając się na obowiązujących przepisach prawnych udowadniał, że funkcjonowanie duszpasterstwa więziennego ma solidną podbudowę normatywną. Jako drugi głos zabrał dr hab. Tadeusz Stanisławski, prof. UZ. Zajął się on problemem Finansowych kosztów zapewnienia wolności sumienia i religii osób pozbawionych wolności, udowadniając, że państwo jest zobowiązane do łożenia na realizację przez więźniów ich konstytucyjnego uprawnienia do aktywnego korzystania z wolności religijnej. Dużym zainteresowaniem zgromadzonej publiczności cieszył się ostatni referat pt. Wolność sumienia i religii osób poddanych internacji psychiatrycznej wygłoszony przez dr Małgorzatę Tomkiewicz (UWM). Autorka udowadniała w nim, że prawa osób odosob- 
nionych ze względu na chorobę psychiczną są realizowane w mniejszym zakresie niż pozbawionych wolności.

Kolejnej, wspólnej sesji, przewodniczył ks. dr hab. Tadeusz Stanisławski, prof. UZ. Poświęcono ją zagadnieniom Ochrony wolności sumienia $i$ religii więźniów. Jako pierwszy głos zabrał dr Michał Poniatowski z UKSW. W swoim wystąpieniu podjął tematykę Środków ochrony prawnej wolności religijnej więźniów, omawiając obowiązujące w tym zakresie regulacje normatywne. Dr Damian Szeleszczuk (KUL) przedstawił referat pt. Prawnokarna ochrona wolności religijnej więźniów. Autor zawodowo zajmujący się dydaktyką prawa karnego, przejrzyście i zrozumiale dla uczestników konferencji przedstawił bardzo skomplikowane zagadnienia. Wybitny znawca tematu, człowiek, który od ponad dwudziestu lat pracuje w więziennictwie, i dużą część swojej pracy badawczej poświecił zagadnieniom praw więźniów, płk dr Jerzy Nikołajew z WSSMiKS w Chełmie i CZSW zaprezentował referat pt. Wolność sumienia i religii z perspektywy osób pozbawionych wolności w Polsce.

Bardzo ciekawe przedłożenia przedstawili kolejni mówcy, byli to w kolejności według wystąpień: dr Sławomir Hypś (KUL), który omówił Odpowiedzialność funkcjonariuszy Stużby Więziennej za naruszenie wolności religijnej więźniów, dr Michał Hucał (ChAT), prezentujący referat pt. Wolność sumienia i religii osób pozbawionych wolności w orzecznictwie ETPCz, mgr Łukasz Czebotar (KUL), z podobnym wystąpieniem pt. Standardy orzecznictwa ETPCz w zakresie wolności sumienia i religii osób pozbawionych wolności i jako ostatni w tym panelu zabrał glos dr Mateusz Pszczyński z UO poruszający zagadnienia Prawa osadzonych do wyżwienia przygotowanego wedtug regut religijnych. Referaty wzbudziły duże zainteresowanie i stały się po raz kolejny na tym sympozjum pretekstem do dyskusji.

Kolejna wspólna sesja została zatytułowana: Kształtowanie się wolności religijnej osób pozbawionych wolności. Jako pierwszy, w zastępstwie dr. hab. Józefa Koredczuka, prof. UWr wystąpił płk dr Jerzy Nikołajew, przedstawiając opracowanie pt. Znaczenie religii $w$ koncepcjach penitencjarnych Juliana Ursyna Niemcewicza i Fryderyka Skarbka. Jak wynikało $\mathrm{z}$ referowanego przedłożenia obaj humaniści, żyjący na przełomie XVIII i XIX w., dostrzegali konieczność wykorzystania opieki religijnej w resocjalizacji więźniów. Kolejnym prelegentem był mjr SW w stanie spoczynku dr Ryszard Maleszyk z referatem zatytułowanym Historyczne aspekty kształtowania się prawa do wolności religijnej więźniów. Tematyka historyczna była również obecna w referacie pt. Kapelani więzienni w II 
Rzeczypospolitej, wygłoszonym przez dr. hab. Andrzeja Szymańskiego, prof. UO. Jako ostatni w tej sesji głos zabrał ks. kmdr dr Zbigniew Jaworski i przedstawił wystąpienie pt. Gwarancje wolności religijnej dla osób przebywajacych $w$ zakładach karnych $i$ w wojsku.

Sympozjum kończyła bardzo ciekawa, można by rzec ekumeniczna sesja, w której autorami referatów byli Naczelni Kapelani Więziennictwa RP. Zatytułowano ją: Raport o aktualnym stanie duszpasterstwa więziennego w Polsce wedtug Naczelnych Kapelanów Więziennictwa RP, a jej moderatorem był płk dr Jerzy Nikołajew. Kościół rzymskokatolicki reprezentował ks. dr Paweł Wojtas, Kościół Ewangelicko-Augsburski w RP ks. Piotr Janik, a Polski Autokefaliczny Kościół Prawosławny ks. dr Piotr Kosiński. Wszyscy duchowni zaprezentowali codzienne realia w jakich funkcjonuje duszpasterstwo więzienne w Polsce, charakteryzując przy tym stan personalny swoich ordynariatów. Po przedstawieniu referatów miała miejsce żywa dyskusja uczestników, a obrady zostały zamknięte przez prof. dr. hab. Tadeusza J. Zielińskiego, który podkreślił, że takie spotkania, jakie miały miejsce w Popowie, są wielce uzasadnione ze względu na „spotkanie” teorii z praktyką.

Dr Marek Bielecki

Wydział Zamiejscowy Prawa i Nauk o Społeczeństwie w Stalowej Woli Katolicki Uniwersytet Lubelski Jana Pawła II

\section{Konferencja naukowa pt. Korelacje wolności religijnej indywidualnej i wspólnotowej, Jastrzębia Góra, 9-10 kwietnia 2015 r.}

W dniach 9-10 kwietnia 2015 r. w Jastrzębiej Górze (Hotel Faleza) odbyła się konferencja naukowa nt. Korelacje wolności religijnej $i$ wspólnotowej. Organizatorami konferencji byli Wydział Prawa i Administracji Uniwersytetu Opolskiego oraz Polskie Towarzystwo Prawa Wyznaniowego.

W konferencji czynny udział wzięło 35 osób, reprezentujących 10 ośrodków naukowych: Uniwersytet Opolski, Katolicki Uniwersytet Lubelski Jana Pawła II, Uniwersytet Kardynała Stefana Wyszyńskiego, Uniwersytet Mikołaja Kopernika w Toruniu, Uniwersytet Rzeszowski, Uniwersytet Papieski Jana Pawła II w Krakowie, Chrześcijańską Akademię Teolo- 